\title{
PERSPECTIVES OF MARINE BIODIVERSITY STUDIES IN ARGENTINA
}

\author{
PERSPECTIVAS DE LOS ESTUDIOS SOBRE BIODIVERSIDAD MARINA EN \\ LA ARGENTINA
}

Vivian A. Lutz ${ }^{1,2}$, Enrique E. Boschi ${ }^{1,2,6}$, Claudia S. Bremec ${ }^{1,2}$, María Berta Cousseau ${ }^{1,3}$, Daniel E. Figueroa ${ }^{3}$, Diego H. Rodríguez $^{1,3}$, Norberto Scarlato ${ }^{2,7}$, María Delia Viñas ${ }^{1,2,3}$, Mirtha N. Lewis ${ }^{1,4}$, Pablo E. Penchaszadeh ${ }^{1,5,6}$, Fabián H. Acuña*, Marina L. Aguirre*, Rut Akselman*, Viviana A. Alder*, Ana Baldoni*, María S. Barría*, Ricardo O. Bastida*, Alicia S. Boraso*, Jorge Calvo*, Claudio Campagna*, Guillermo Cañete*, María C. Cassia*, Patricia M. Cervellini*, Gustavo E. Chiaramonte*, Marcela Costagliola*, Guillermina Cosulich*, María C. Daponte*, Juan M. Díaz de Astarloa*, Rodolfo Elías*, Graciela B. Esnal*, Adriana C. Excoffon*, Hugo Freije*, Susana García de la Rosa*, Gabriel N. Genzano*, Diego A. Giberto*, Raúl Guerrero*, Walter Helbling*, Mónica S. Hoffmeyer*, Inés S. Incorvaia*, Oscar Iribarne*, Andrés J. Jaureguizar*, Mariela Kogan*, Gustavo A. Lovrich*, Adrián O. Madirolas*, Juan P. Martin*, Patricia Martos*, María L. Mendoza*, Silvina Menu Marque*, Hermes W. Mianzán*, Elba R. Morriconi*, Rubén M. Negri*, Sandra Obenat*, Catalina T. Pastor de Ward*, Laura B. Pérez de Fankhauser*, Flavio Quintana*, Raúl Reta*, Rita Rico*, Ana M. Roux*, Marina E. Sabatini*, Marcelo A. Scelzo*, Laura Schejter*, Adrián C.M. Schiavini*, Ricardo I. Silva*, María G. Silvoni*, Eduardo Spivak*, María I. Trucco*, Eduardo A. Vallarino*, Diego G. Zelaya*

${ }^{1}$ Consejo Nacional de Investigaciones Científicas y Técnicas

${ }^{2}$ Instituto Nacional de Investigación y Desarrollo Pesquero, Paseo Victoria Ocampo No 1 (B7602HSA) Mar del Plata, Argentina

${ }^{3}$ Departamento de Ciencias Marinas, Universidad Nacional de Mar del Plata, Deán Funes 3350 (7600), Mar del Plata, Argentina

${ }^{4}$ Centro Nacional Patagónico, Boulevard Brown s/n (U9120ACV) Puerto Madryn, Argentina

${ }^{5}$ Museo Argentino de Ciencias Naturales Bernardino Rivadavia, Avenida Angel Gallardo 470 (C1405DJR), Buenos Aires, Argentina

${ }^{6}$ Facultad de Ciencias Exactas y Naturales, Universidad de Buenos Aires, Ciudad Universitaria (C1428EHA), Buenos Aires, Argentina

${ }^{7}$ Departamento de Biología, Universidad Nacional de Mar del Plata, Deán Funes 3350 (7600), Mar del Plata, Argentina

*Addresses for these researchers, cited here in alphabetical order, are listed in Appendix II

\begin{abstract}
This paper provides an overview of the research being carried out at the moment by a group of Argentinean scientists working on the subjects of marine biodiversity and oceanography. When the idea of the Census of Marine Life (CoML) was proposed following the Symposium held during the IAPSO-IABO conference in Mar del Plata in October 2001, there was a wide response from the marine scientific community. Information about current research projects, as well as plans for future work in the context of the CoML, were then obtained from about 70 scientists (Appendix I) belonging to 12 institutions located along the Argentinean coast (Appendix II, Figure 1). This has been used to illustrate what is currently being pursued in marine biodiversity in Argentina and which subjects are considered as priority for future research in the area. This paper is, thus, not an historical update of the knowledge of marine biodiversity, but it attempts to give an idea of the current situation and what is planned for the future. The development of an extensive database of what is known on marine biodiversity in the region is considered to be a necessity, but it constitutes a complete project on its own; as such it is included in the proposals for future work (see Future Work in this paper). It is emphasised that this synthesis is not exhaustive in the content of the topics being studied or in the number of researchers working in marine biodiversity in the country. It is, though, considered to be a representative sample of the knowledge in marine science in Argentina today. This is a starting point for the CoML project in South America and it is hoped that, as it develops, it will be improved by the active participation, advice and experience of many other scientists in the region.
\end{abstract}

KEYwORDS: Oceanography, census of marine life. 


\section{RESUMEN}

En este artículo nosotros intentamos dar un panorama sobre la investigación llevada a cabo en este momento por un grupo de científicos argentinos que trabajan en los temas de biodiversidad marina y oceanografía. Cuando comenzamos a distribuir la idea del Censo de la Vida Marina (CoML), luego del simposio desarrollado durante la conferencia del IAPSO-IABO en Mar del Plata en octubre del 2001, encontramos una amplia respuesta en la comunidad científica marina. Recopilamos entonces información acerca de los proyectos de investigación en curso, así como también intereses para futuros trabajos en el contexto del CoML, de cerca de 70 investigadores (Apéndice I) pertenecientes a doce instituciones ubicadas a lo largo de la costa Argentina (Apéndice II, Figura 1). Con el objeto de hacer un buen uso de esta valiosa información decidimos enfocarnos en mostrar lo que se está realizando en la actualidad en biodiversidad marina en Argentina y cuáles son los temas considerados prioritarios a continuar desarrollándose en un futuro por los investigadores que trabajan en esta área. Por lo tanto, este documento no es una puesta al día del conocimiento sobre biodiversidad marina en Argentina, pero ciertamente da una idea de a dónde ha llegado y hacía dónde pretende ir. Nosotros estamos de acuerdo que construir una base de datos extensiva de lo que se conoce sobre biodiversidad en la región es una necesidad, pero entendemos que esto constituye un proyecto en sí mismo, y por lo tanto decidimos incluirlo como una de las propuestas a futuro (ver Future Work en este documento). Debemos enfatizar que esta síntesis no es exhaustiva en el contenido de temas en estudio ni en el número de investigadores que trabajan en biodiversidad marina en el país. Creemos, sin embargo, que es una muestra representativa de lo que se está realizando en ciencias marinas en Argentina hoy. Este es un punto de partida para el trabajo del CoML en Sudamérica y nosotros esperamos que a medida que se desarrolle se verá mejorado por la participación activa, los consejos y la experiencia de muchos otros científicos en la región.

Palabras Claves: Oceanografía, censo de la vida marina.

\section{INTRODUCTION}

\section{The Argentine SEA}

Argentina has an extensive, 4,000 km long, maritime littoral on the South Western Atlantic Ocean. It includes four large gulfs (San Jorge, San Matías, Nuevo, and San José) and the Río de la Plata estuary. The adjacent continental shelf out to the shelfbreak has a surface area of ca. 960,000 km²; beyond this, the depth increases steeply.

The Argentinean continental shelf has a smooth topography and variable width. To the North $\left(38^{\circ} \mathrm{S}\right)$, it is $210 \mathrm{~km}$ wide and, to the South $\left(52^{\circ} \mathrm{S}\right)$, it extends out to $850 \mathrm{~km}$ from the coast. Sediments along the shelf are of variable composition. To the North, sand, gravel, and shells predominate, whereas, to the South, there is mainly a mixture of sand and gravel. In some areas of Golfo San Jorge, Southern Patagonian Coasts and at the shelf-break, mud sediments are abundant. Rocky bottoms are found on the area offshore from the Golfo San Jorge, as well as in some small parts of the central continental shelf.

Three main water masses are recognized: coastal waters, shelf waters, and slope waters. Low Salinity Coastal waters are influenced by the continental runoff from main rivers, the Canales Fueguinos and the Magellan Straits. These waters vary in temperature and cover areas such as the estuary of Río de la Plata, El Rincón, and the coast of Santa Cruz Province. Coastal waters of high salinity are found off Buenos Aires Province and at the mouths of the gulfs San Matías and Nuevo. Shelf waters cover the central zone of the shelf between $38^{\circ} \mathrm{S}$ to $55^{\circ} \mathrm{S}$. Slope waters cover the outermost zone of the shelf, on the shelf-break.

Some conspicuous features are relevant to the regional oceanography and species distributions: the Malvinas Current of Subantarctic origin, which runs northward parallel to the shelf-break; the Magallanes Strait, separating Tierra del Fuego from the mainland and connecting the Pacific and Atlantic Oceans; and the Río de la Plata, discharging large volumes of fresh water and its sediments to the ocean. Several oceanographic fronts are clearly distinct.

Several attempts have been made to classify the Argentinean Sea into biogeographical provinces. From a biological point of view, 2 main provinces have been proposed. The Provincia Magallánica of cold waters broadly covers the Southern Patagonian 
coast and shelf and widens offshore and extends northwards along the outermost zone of the shelf. The Provincia Argentina of warmer waters covers the coast from North Patagonia, approximately from Península Valdés, towards the North including the coast of the Buenos Aires Province, Uruguay and Southern Brazil (up to $\sim 23^{\circ} \mathrm{S}$ ).

\section{MAIN SUBJECTS OF RESEARCH}

\section{Seabirds And Marine Mammals}

The Argentine Sea is characterized by a high diversity of marine birds and mammals. About 80 species of birds depend on marine habitats for both breeding and foraging and more than 40 marine mammal species have been recorded in coastal and offshore waters. Research projects on these groups are conducted along the whole of the coast of Argentina. The activity is based mainly in Tierra del Fuego (CADIC), northern Patagonia (CENPAT), and northern Buenos Aires Province (UNMdP) (see Figure 1), 6 scientists from these institutes having contributed to this paper.

The main research focus is on behavioural demography and trophic studies and the assessment of interaction with fisheries. Studies, using satellite telemetry, of the social behaviour of birds and mammals at sea are complemented by population assessment and long-term monitoring of coastal communities. Demographic data for some populations span over more than 15 years. Trophic studies include the analysis of diet, habitat use, and foraging strategies. The study of the interaction of birds and mammals with coastal and shelf fisheries recorded mortalities caused by coastal gillnets, trawling, and longline operations.

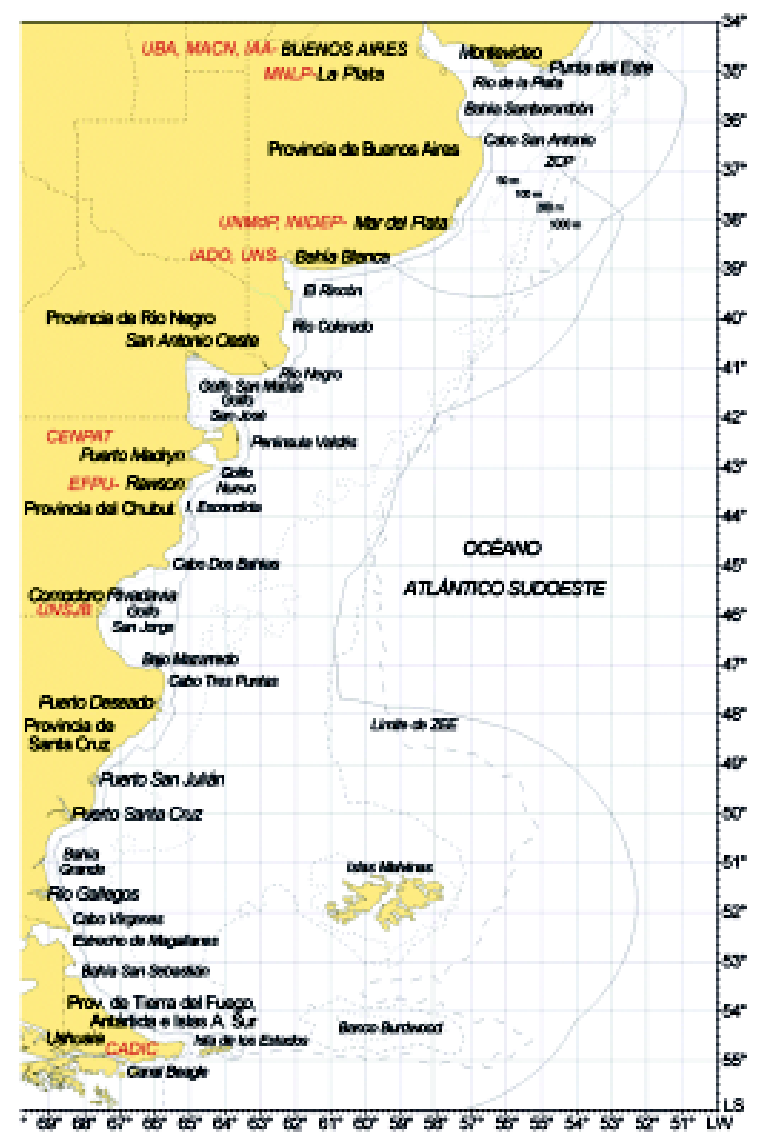

FIGURE 1. Location of the Marine Science Institutions of Argentina referred to in this paper.

Figura 1. Ubicación de las Instituciones dedicadas a las Ciencias Marinas en Argentina representadas en este artículo. 
Researchers have identified certain urgent aspects of conservation, particularly for several threatened species of seabirds (e.g. Southern Giant Petrels) and marine mammals (e.g. La Plata Dolphin). High importance was given to linking the research findings to the sustainable use and conservation of marine and coastal biodiversity resources. National and international laws protect most of the species and several coastal communities exist within small marine protected areas. The implementation of effective conservation strategies and the creation of new management procedures for Marine Protected Areas are recommended.

Population trends, interaction with fisheries, the monitoring of offshore species by satellite telemetry, pollution studies, and the study of the health of the wildlife are considered powerful tools for the utilization of these top predators as indicators of environmental changes.

\section{ICHTHYOLOGY}

The Argentine Sea represents a transitional zone for the ichtyofauna. Fish biodiversity is, as a result, lower than in tropical ichthyofauna, with fewer than 500 species actually identified. A wide range of research topics concerning marine fish is currently carried out in Argentina. Twelve scientists dedicated to this field, working at MACN, INIDEP, UNMdP, and CADIC have shown interest in participating in the first CoML initiative.

Several studies cover aspects of fish biology, taxonomy, and trophic ecology. Some are focused on Pleuronectiformes and Anguilliformes. In the Patagonian Region, predominantly in Subantarctic waters, the research is concentrating on osteichthyan and chondrichthyan fisheries biology as well as on the physiology of reproduction, energy budgets, and behaviour. Fish stock identification using parasites as biological tags is also being investigated. Off the coast of Buenos Aires, where the waters are warmer, the studies are related to biodiversity with special emphasis on the determination and distribution of fish assemblages. A project on spatial and temporal variations in fish distribution is carried out in the estuarine environment of the Mar Chiquita coastal lagoon (Buenos Aires Province).

Some economically important species are being monitored for fishery purposes. This task is carried out by fisheries scientists on board research vessels and by trained observers on commercial ships. Together with traditional methods for fish assessment, such as bottom trawl surveys, acoustic methods are also intensively employed for monitoring several species of demersal and pelagic fish at locations ranging from coastal waters and estuaries to the continental slope.

\section{BENTHOS}

The study of the benthos in Argentina includes several fields of research; the information given here summarises that provided by 26 scientists from institutions located in Mar del Plata (UNMdP, INIDEP), La Plata (UNLP), Buenos Aires (UBA), Puerto Madryn (CENPAT), Comodoro Rivadavia (UNPSJB), and Ushuaia (CADIC).

Investigations related to particular taxonomic groups are mainly dedicated to the study of:

- The taxonomy, geographical distribution, and biogeography of Anthozoa, Hydrozoa, Crustacea, Molluscs, Nematoda, Polychaeta, Echinodermata, and Tunicata from the Argentinean continental shelf and the adjacent hydrographic Subantarctic and Antarctic regimes. Modern methods (spermiotaxonomy in Crustacea) and classical techniques (histology and histochemistry) are used for morphological studies.

- The reproductive biology of Cnidaria from the Argentinean Continental Shelf (histological techniques), and of Polychaeta, Molluscs, and Crustacea from Buenos Aires and Asteroidea from Patagonian coastal habitats. Classical methods are used.

- The taxonomy and utilization of seaweeds from Patagonia (Chubut, Santa Cruz and Tierra del Fuego) and other Subantarctic and Antarctic areas, by means of morphometry and microscopy. Also, the reproduction and culture of marine algae in culture media (unicellular) and cultivation chambers (multicellular).

- The population genetics of the Mytilidae from the South American Atlantic using enzyme polymorphisms, basic cytogenetics, and banding techniques. 
Other studies concern benthic assemblages as listed below:

- The ecology of coastal habitats and invertebrate species (Polychaeta, Crustacea) from the province of Buenos Aires, in some cases in comparison with the coastal environments of Uruguay and Brazil. Experimental programs and classical collection and study techniques are also being developed.

- Benthic indicators of organic enrichment in the Mar del Plata subtidal and harbour area using classical sampling (grabs, corers) and experimental and micronucleus analysis to assess pollution.

- Biodiversity and community structure associated with infralittoral bottoms in El Rincón, the Río de la Plata estuary, the Península Valdes, San Jorge Gulf and the Argentinean Continental Shelf. Also the benthic feeding grounds and trophic ecology of demersal fishes on the Buenos Aires shelf. Material is obtained with conventional gears (dredges, grabs, otter trawls) and analyzed using multivariate techniques.

- Comparative studies of the composition and paleobiodiversity of molluscan assemblages from Quaternary marine deposits from Argentina and other areas of the Southern Hemisphere using systematic, biometrical and geochemical analyzes and radiocarbon dating.

- Comparative physiological analysis of Subantarctic benthic communities, currently involving molluscs and decapods from Tierra del Fuego and the Beagle Channel, by means of energetic determinations (oxygen consumption).

\section{ZOOPLANKTON}

Twelve Argentinean scientists working on marine and estuarine zooplankton have so far shown an interest in joining future CoML projects in South America. Most of them are based in research institutions located in the Buenos Aires Province, such as INIDEP, UBA, and IADO.

A large number of studies are currently being conducted. Most of them are field work, mainly focused on the taxonomy, distribution, and abundance of different taxa in relationship to environmental condi- tions. Almost all size groups are included: nanoplankton, microzooplankton (ciliates, dinoflagellates, radiolarians, and foraminifers), mesozooplankton (copepods, cladocerans, decapod larvae, and appendicularians), and macrozooplankton (amphipods, euphausiids, mysids, thaliaceans, doliolids, chaetognaths, ctenophores, medusae).

The Buenos Aires shelf and the estuarine regions of Río de la Plata and Bahía Blanca are the most intensively studied areas while the shelf-break and the Patagonian areas have been considerably less explored. The few studies of zooplankton composition and biomass in the southern Patagonian shelf region were mainly carried out during the austral summer. In some coastal areas of Antarctica, there are at least 4 scientists studying the spatial and temporal distribution of several zooplankton groups (microzooplankton, tunicates, copepods, etc.).

Much effort is aimed at understanding the influence of the environment on the population dynamics of some target species (reproduction, distribution, seasonal and spatial variation, and migration patterns). Another focus of current research is the analysis of the structure of plankton communities and food webs. This approach has been employed in some areas of Buenos Aires, northern Patagonian shelves, and the Río de la Plata estuary. In this regard, several specialists in diverse taxonomic groups are conducting interdisciplinary studies in order to explain the processes underlying the formation of the observed plankton assemblages. The influence of frontal systems on the planktonic communities (from bacterioplankton to macrozooplankton) is being studied in the Río de la Plata estuary.

While most of the work is restricted to investigating spatial distribution, there are some time series of data such as those for the Bahía Blanca estuary (1986-1998) and the Nueva and Engaño bays (19941998). In these locations, zooplankton collection is accompanied by the gathering of hydrographic data (see the Biological Oceanography section). In addition, an approximately monthly sampling program was started in January 2000 at a fixed station near Mar del Plata harbour ( $\left.38^{\circ} 28^{\prime} \mathrm{S}, 5^{\circ} 41^{\prime} \mathrm{W}\right)$. Here, plankton sampling includes all size fractions from bacterioplankton to macrozooplankton and chemical and physical parameters are measured at the same time (see the Biological Oceanography section). Classical taxonomy and standard microscopy count- 
ing have been used in meso and macrozooplankton studies. Hydroacoustics is routinely employed for monitoring spatial patterns of macrozooplankton. In the case of ciliates, methods include electronic microscopy and cell counts by inverted microscopy, Protargol staining and fluorescence techniques. Although the experimental approach is at present much less developed, some work is under way examining copepod egg production in a frontal region and the nutrition of estuarine copepods.

\section{Biological and Chemical Oceanography}

Three research groups (7 scientists) working on biological and chemical oceanography in relation to phytoplankton dynamics over the Argentinean Shelf have contributed to this paper. A common point of interest among these research groups is the development of time series studies at fixed locations.

The first of these has been carried out at two sites in the Bahía Blanca estuary $\left(38^{\circ} 45 \mathrm{~S} 62^{\circ} 20 \mathrm{~W}\right.$, Buenos Aires Province) since 1974. This project, developed at IADO, aims, as its main objective, to relate various aspects of chemical oceanography to coastal primary production and eutrophication processes in the area. Sampling is performed every 15 days. Variables measured at these sites include: 1) Phytoplankton species abundance (optical microscopy); 2) Chlorophyll$a$ concentration (spectrophotometry); 3) Temperature; 4) Irradiance (PAR quantum meter); 5) Nutrient concentrations (autoanalyzer); 6) Dissolved oxygen (Winkler method); 7) Salinity (conductivity); 8) Gross and net primary production $\left({ }^{14} \mathrm{C}\right.$ incorporation, oxygen evolution); and 9) Others such as turbidity, tidal level, and meteorological conditions.

A second time series study at Bahía Engaño $\left(43^{\circ} \mathrm{S}\right.$ $65 \mathrm{~W}$; Chubut Province) was started in 2000. This project, developed at EFPU, aims to assess the impact of solar ultraviolet radiation (UV) on the primary productivity of natural phytoplankton assemblages. The station is sampled every month, the data obtained including: 1) Phytoplankton species abundance (optical microscopy); 2) Chlorophyll- $a$ concentration (fluorometry); 3) Temperature (submersible thermometer); 4) Irradiance (PAR-UV quantum meter); 5) Absorption spectra of phytoplankton and detritus (spectro- photometry); 6) Primary production $\left({ }^{14} \mathrm{C}\right.$ incorporation; oxygen evolution; the use of PAM fluorometry is envisaged); and 7) UV-absorbing compounds on phytoplankton (spectrophotometry). Another time series study, carried out at a coastal station (EPEA: Estación Permanente de Estudios Ambientales) located off the Buenos Aires Province ( $\left.38^{\circ} 28^{\prime} \mathrm{S}, 57^{\circ} 41^{\prime} \mathrm{W}\right)$, has been sampled since 2000. This project, known as DiPlaMCC (Dinámica del Plancton Marino y Cambio Climático) is based at INIDEP. The main aim is to understand how variations in the dynamics and diversity of plankton communities are linked to climate change. The station is sampled monthly and the project is expected to run for about 10 years. The data being gathered include: 1) Phytoplankton species abundance (optical microscopy); 2) Chlorophyll- $a$ concentration (fluorometry); 3) Temperature, density, and salinity (CTD); 4) Irradiance (PAR-UV quantum meter); 5) The absorption spectra of phytoplankton and detritus (spectrophotometry); 6) Nutrient concentrations (autoanalyzer); 7) Dissolved oxygen (Winkler method); 8) Absorption spectra of coloured dissolved organic matter (spectrophotometry); 9) Qualitative and quantitative information on ultraphytoplankton $(<5 \mathrm{~m})$ (epifluorescence microscopy; occasionally flow cytometry; the use of molecular techniques is envisaged); and 10) Bacterioplankton abundance and composition (epifluorescence microscopy).

In addition to these time series projects, a variety of other studies on phytoplankton are being developed. Some of them involve regional descriptions of species composition sampled during INIDEP research cruises (e.g., in different areas of the Buenos Aires Shelf, the frontal region off the Río de la Plata, Golfo San Jorge, and the southern Patagonian shelf). Other studies involve: physiological aspects of the effect of UV-radiation on phytoplankton in relationship to vertical mixing, the bioaccumulation of UV-absorbing-compounds, and interaction with the zooplankton (Playa Unión area, Chubut); the monitoring of primary production and chlorophyll in the microphytobenthos of salt marshes (Bahía Blanca area, Buenos Aires); and laboratory experiments and modelling to understand nutrient uptake by phytoplankton in the Bahía Blanca estuary. The abundance, spatial distribution, and role of the bacterioplankton in the food web in the Río de la Plata estuary are also being studied (INIDEP). 
Physical oceanography

A group of 4 scientists at INIDEP are involved with descriptive physical oceanography in the Argentinean shelf and shelf-break areas. The variables monitored include continuous conductivity/temperature profiles (CTD) sometimes with an in situ fluorometer attached to the CTD. Salinity and temperature at discrete depths are also occasionally measured. There is a data set $(95 \%$ are CTD) for about 11,041 physical oceanographic stations (up to May 2002) distributed over the whole of the Argentinean Shelf. Quality control, calibration and editing are carried out on CTD data set. The main research project is "The Physical Oceanography of Argentinean Continental Shelf Ecosystems". The research team involved with this collaborates with physical, biological, fisheries, and ichthyological studies developed by scientists at INIDEP, UNMdP, and UNS. Topics being studied include: 1) The degree of coupling between physical and biological processes, taking the Patagonian scallop as a case study (on the outer shelf and slope, $34^{\circ}-55^{\circ} \mathrm{S}$ ); 2) A hydrographic study of the Río de la Plata and its frontal system; 3) A study of the physical oceanographic regimes of the Northern Argentinean Continental Shelf $\left(33^{\circ}-43^{\circ} \mathrm{S}\right)$; 4) A numerical simulation of the oceanic circulation over the continental shelf and its interaction with the Malvinas and Brazil Currents; 5) An analysis of the relationship between the presence and abundance of the Patagonian anchovy and the main physical features of the area $\left(41^{\circ}-45^{\circ} \mathrm{S}\right)$; and 6$)$ The environmental characterization of the areas of distribution, spawning, and breeding of several marine fish of commercial interest in the Patagonian Shelf $\left(41^{\circ}-55^{\circ} \mathrm{S}\right)$ and coastal sectors of Argentina and Uruguay.

\section{FUtURE WORK}

Some of the ideas for future work on biodiversity which emerged as those of major interest for the group of researchers in Argentina participating in this first initiative of the CoML follow. It is hoped that these ideas will be discussed and integrated with similar ones from colleagues in South America and the northern hemisphere to be eventually incorporated into proposals of the type promoted by CoML.
- Creation of a GIS-Database. This will involve the integration of biological and oceanographic historical data pertaining to the Argentinean Continental Shelf and those from other countries concerned into a systematic geographical database. This should, in the long-term, be incorporated into a global system such as OBIS (Ocean Biogeographical Information System). The proposal has been reinforced by the initiative of librarians at INIDEP who wish to cooperate with researchers in CoML projects by creating interactive bibliographic databases for particular studies in partnership with the libraries of other participating institutions in South America.

- Biogeographical assessment. This proposes a revision of existing attempts to partition the shelf areas around South America into biogeographical provinces in the Large Marine Ecosystem (LME) context. For this purpose, historical and contemporary databases as well as new results arising from eventual CoML projects would be used. In this context, some intensive biological/ ecological studies of key species within each biogeographical province will need to be pursued.

- Integrative studies of large marine ecosystems. This would initiate studies on the diversity and dynamics of organisms in relation to oceanographic conditions in poorly known ecosystems such as shallow waters, the continental shelfbreak in the South Western Atlantic, the shelf area off south Patagonia, and the Antarctic region. For these studies, it has been suggested that there should be dedicated scientific cruises as well as a program of scientific observers on board commercial ships and satellite technology. In connection with this idea, there is an initiative to create an oceanic protected area along the continental shelf-break within the framework of ecosystem management.

- Time series network around South America. This suggests the creation of a network of time series studies of organism diversity and dynamics together with oceanographic conditions at fixed locations around South America. This would aim to integrate the individual time series studies on the Argentinean coast with new stations distributed around the South American coast covering the main biogeographical provinces. 
- Comparative studies of estuaries and coastal lagoons. This proposes comparative studies of biodiversity and environmental conditions in estuaries and coastal lagoons of South America involving species composition, abundance, seasonal variations, and trophic relationships within taxonomic groups.

Factors identified as essential for the advancement of marine research in the region were:

- Development of human resources. More scientists and technical assistants will be needed for future taxonomical and oceanographic studies. For this, it would be sensible to take advantage of the knowledge of existing experts in taxonomy and of the reference collections in museums. The optimization of resources, both human expertise and equipment, will be necessary. Interaction between countries through courses, seminars and workshops on specific topics of technologies for the detection and assessment of marine life should be developed.

- Incorporation and testing of new technologies in the region. Technology plays a major role in making a census of marine life. Hence, a common interest among researchers participating in this initiative is the application of newly developed techniques such as:

- Molecular techniques for taxonomic and stock identification.
- Hydroacoustic techniques for identification and abundance assessments of stocks.

- Remote sensing for the estimation of primary production and the monitoring of electronically tagged individuals.

- Pulse repetitive fluorometry for the determination of primary production.

- Underwater video cameras for the identification and abundance assessments of planktonic and benthic organisms.

- Tagging and recapture of organisms to study their migration patterns.

- Remotely operated vehicles for the exploration of poorly known topographic features (e.g. submarine canyons).

\section{THE UNKNOWABLE}

In this paper, an attempt has been made to indicate what is considered to be of top priority in the next 10 years within the CoML program. Knowledge generated by the proposed projects will certainly create further questions. In this sense, new lines of research will follow these first steps.

The rapid development of new technologies will make possible, in the near future, achievements which cannot be foreseen at the present time as well as reduce the effort necessary to accomplish certain tasks. 
Marine biodiversity in Argentina: LUTZ, V. ET AL.

ApPENDIX I: List of Argentinian researchers who contributed to this paper.

Apendice I. Lista de investigadores argentinos, quienes contribuyen a este trabajo.

\begin{tabular}{|c|c|c|c|}
\hline NAME & EMAIL & Research SubJect & INSTITUTION \\
\hline Acuña, Fabián H. & facuna@mdp.edu.ar & Benthos (Cnidarians) & UNMdP \\
\hline Aguirre, Marina L. & maguirre@museo.fcnym.unlp.edu.ar & Benthos (Paleoecology) & MLP \\
\hline Akselman, Rut & rutaks@inidep.edu.ar & Biol. Oceanography (Phytoplankton) & INIDEP \\
\hline Alder, Viviana A. & viviana@bg.fcen.uba.ar & Zooplankton (Microplankton) & UBA-IAA \\
\hline Baldoni, Ana & baldoni@inidep.edu.ar & Physical Oceanography & INIDEP \\
\hline Barría, María S. & sbarria@criba.edu.ar & Zooplankton (Ciliophora) & UNS-IADO \\
\hline Bastida, Ricardo O. & rbastida@mdp.edu.ar & Benthos-Marine Mammals & UNMdP \\
\hline Boraso, Alicia S. & aboraso@sinectis.com.ar & Benthos (Botany) & UNPSJB \\
\hline Boschi, Enrique E. & eboschi@inidep.edu.ar & Benthos (Decapod crustaceans) & INIDEP \\
\hline \multirow[t]{2}{*}{ Bremec, Claudia S. } & cbremec@inidep.edu.ar & Benthos (Fishing disturbances - & \\
\hline & & Polychaets) & INIDEP \\
\hline Calvo, Jorge & jcem@arnet.com.ar & Benthos (Molluscs - Fishes) & CADIC \\
\hline Campagna, Claudio & campagna@satlink.com & Marine Mammals & CENPAT \\
\hline Cañete, Guillermo & gcanete@inidep.edu.ar & Ichthyology (Fisheries) & INIDEP \\
\hline Cassia, María C. & mccassia@inidep.edu.ar & Ichthyology (Fisheries) & INIDEP \\
\hline Cervellini, Patricia M. & pcervell@criba.edu.ar & Zooplankton (Crustacean larvae) & UNS \\
\hline Chiaramonte, Gustavo E. & gchiaram@mail.retina.ar & Ichthyology (Elasmobranchs) & MACN \\
\hline \multirow[t]{2}{*}{ Costagliola, Marcela } & mcosta@inidep.edu.ar & Biol. Oceanography & \\
\hline & & (Bacterioplankton) & INIDEP \\
\hline Cosulich, Guillermina & biblio@inidep.edu.ar & Library & INIDEP \\
\hline Cousseau, María B. & mbcousse@mdp.edu.ar & Ichthyology & UNMdP \\
\hline \multirow[t]{2}{*}{ Daponte, María C. } & daponte@bg.fcen.edu.ar & Zooplankton (Tunicates - & \\
\hline & & Chaetognaths) & UBA \\
\hline Díaz de Astarloa, Juan M. & astarloa@mdp.edu.ar & Ichthyology & UNMdP \\
\hline Elías, Rodolfo & roelias@mdp.edu.ar & Benthos (Bioindicators) & UNMdP \\
\hline Esnal, Graciela B. & esnal@bg.fcen.uba.ar & Zooplankton - Benthos (Tunicates) & UBA \\
\hline Excoffon, Adriana C. & excoffon@mdp.edu.ar & Benthos (Cnidarians) & UNMdP \\
\hline Figueroa, Daniel E. & dfiguer@mdp.edu.ar & Ichthyology & UNMdP \\
\hline \multirow[t]{2}{*}{ Freije, Hugo } & qmfreije@criba.edu.ar & Chem. Oceanography & \\
\hline & & (Phytoplankton) & UNS \\
\hline García de la Rosa, Susana & sdrosa@mdp.edu.ar & Ichthyology (Trophism) & UNMdP \\
\hline Genzano, Gabriel N. & genzano@mdp.edu.ar & Benthos (Cnidarians) & UNMdP \\
\hline Giberto, Diego A. & diegogiberto@inidep.edu.ar & Benthos (Trophism) & INIDEP \\
\hline
\end{tabular}


Gayana 67(2), 2003

Continuation APENDix I.

Continuación ApÉndice I.

\begin{tabular}{|c|c|c|c|}
\hline NAME & EMAIL & Research SubJect & INSTITUTION \\
\hline Helbling, Walter & whelbling@efpu.com.ar & $\begin{array}{l}\text { Biol. Oceanography (Photobiology - } \\
\text { Phytoplankton) }\end{array}$ & EFPU \\
\hline Hoffmeyer, Mónica S. & bmhoffme@criba.edu.ar & Zooplankton (Crustaceans - Ecology) & IADO \\
\hline Incorvaia, Inés S. & incor@inidep.edu.ar & Ichthyology (Parasitology) & INIDEP \\
\hline Iribarne, Oscar & osiriba@mdp.edu.ar & Benthos (Coastal ecology) & UNMdP \\
\hline Jaureguizar, Andrés J. & $\begin{array}{l}\text { ajj@inidep.edu.ar // } \\
\text { jaureguizara@mar.dfo-mpo.gc.ca }\end{array}$ & Ichthyology (Ecology) & INIDEP \\
\hline Kogan, Mariela & mkogan@inidep.edu.ar & Zooplankton (Microzooplankton) & INIDEP \\
\hline Lewis, Mirtha N. & lewis@cenpat.edu.ar & Marine Mammals & CENPAT \\
\hline Lovrich, Gustavo A. & Lovrich@tierradelfuego.org.ar & Benthos (Crustaceans) & CADIC \\
\hline Lutz, Vivian A. & vlutz@inidep.edu.ar & $\begin{array}{l}\text { Biol. Oceanography (Bio-optics - } \\
\text { Phytoplankton) }\end{array}$ & INIDEP \\
\hline Madirolas, Adrián O. & adrian@inidep.edu.ar & $\begin{array}{l}\text { Ichthyology-Zooplankton } \\
\text { (Hydroacoustics) }\end{array}$ & INIDEP \\
\hline Martin, Juan P. & jpmartin@mdp.edu.ar & Benthos (Ecology) & UNMdP \\
\hline Martos, Patricia & pmartos@inidep.edu.ar & Physical Oceanography & $\begin{array}{l}\text { INIDEP- } \\
\text { UNMdP }\end{array}$ \\
\hline Mendoza, María L. & mlmendoza@arnet.com.ar & Benthos (Botany) & CADIC \\
\hline Menu Marque, Silvina & silvina@bg.fcen.uba.ar & Zooplankton (Copepods) & UBA \\
\hline Mianzan, Hermes W. & hermes@inidep.edu.ar & Zooplankton (Gelatinous plankton) & INIDEP \\
\hline Morriconi, Elba R. & jcem@arnet.com.ar & Benthos (Molluscs - Fishes) & CADIC \\
\hline Negri, Rubén M. & negri@inidep.edu.ar & Biol. Oceanography (Phytoplankton) & INIDEP \\
\hline Obenat, Sandra & sobenat@mdp.edu.ar & Benthos (Estuarine invertebrates) & UNMdP \\
\hline Pastor de Ward, Catalina T. & pastor@cenpat.edu.ar & Benthos (Nematoda - Polychaets) & CENPAT \\
\hline Penchazadeh, Pablo E. & pablop@mail.retina.ar & Benthos (Molluscs) & $\begin{array}{l}\text { MACN- } \\
\text { UBA }\end{array}$ \\
\hline Pérez de Fankhauser, Laura & fankhauser@infovia.com.ar & Benthos (Botany) & UNPSJB \\
\hline Quintana, Flavio & quintana@cenpat.edu.ar & Seabirds & CENPAT \\
\hline Reta, Raúl & reta@inidep.edu.ar & Physical Oceanography & INIDEP- \\
\hline UNMdP & & & \\
\hline Rico, Rita & rrico@inidep.edu.ar & Ichthyology & INIDEP \\
\hline Rodríguez, Diego H. & dhrodri@mdp.edu.ar & Marine Mammals & UNMdP \\
\hline Roux, Ana M. & anaroux@inidep.edu.ar & Benthos (Fishing disturbances) & INIDEP \\
\hline
\end{tabular}


Marine biodiversity in Argentina: LUTZ, V. ET AL.

Continuation APENDix I.

Continuación ApÉndice I.

\begin{tabular}{llll}
\hline \multicolumn{1}{c}{ NAME } & \multicolumn{1}{c}{ EMAIL } & \multicolumn{1}{c}{ RESEARCH SuBJECT } & Institution \\
\hline Scarlato, Norberto & scarlato@inidep.edu.ar & Ichthyology (Fisheries) & INIDEP \\
Scelzo, Marcelo A. & mascelzo@mdp.edu.ar & Benthos (Decapod crustaceans) & UNMdP \\
Schejter, Laura & schejter@inidep.edu.ar & Benthos (Fishing disturbances) & INIDEP \\
Schiavini, Adrián C.M. & schiavini@arnet.com.ar & Seabirds - Marine Mammals & CADIC \\
Silva, Ricardo I. & risilva@inidep.edu.ar & Biol. Oceanography (Phytoplankton) & INIDEP \\
Silvoni, María G. & biblio@inidep.edu.ar & Library & INIDEP \\
Spivak, Eduardo & espivak@mdp.edu.ar & Benthos (Decapod crustaceans) & UNMdP \\
Trucco, María I. & mtrucco@mdp.edu.ar & Benthos (Genetics) & UNMdP \\
Vallarino, Eduardo A. & evallari@mdp.edu.ar & Benthos (Bioindicators) & UNMdP \\
Viñas, María D. & mdvinas@inidep.edu.ar & Zooplankton (Crustaceans - Ecology) & INIDEP \\
Zelaya, Diego G. & dzelaya@ museo.fcnym.unlp.edu.ar & Benthos (Micromolluscs) & MLP
\end{tabular}


Gayana 67(2), 2003

ApPENDIX II: List of Argentinean Marine Research Institutions Represented in this document.

APENDICE II. Lista de Instituciones Argentinas de Investigación Marina representados en este documento.

\begin{tabular}{|c|c|c|c|c|}
\hline ACRONYM & NAME & ADDRESS & FAX & Website \\
\hline CADIC & $\begin{array}{l}\text { Centro Austral de } \\
\text { Investigaciones Científicas }\end{array}$ & $\begin{array}{l}\text { Avda. Malvinas } \\
\text { Argentinas s/n. - } \\
\text { C.C.92(V9410BFD) } \\
\text { Ushuaia, Argentina }\end{array}$ & $+54-2901-430644$ & www.tierradelfuego.org.ar/cadic/ \\
\hline CENPAT & Centro Nacional Patagónico & $\begin{array}{l}\text { Boulevard Brown s/n } \\
\text { (U9120ACV) Puerto } \\
\text { Madryn, Argentina }\end{array}$ & $+54-2965-451543$ & www.cenpat.edu.ar \\
\hline EFPU & $\begin{array}{l}\text { Estación Fotobiología } \\
\text { Playa Unión }\end{array}$ & $\begin{array}{l}\text { Casilla de Correos } \\
\text { N}^{\circ} 153 \text { (9100) Trelew, } \\
\text { Chubut, Argentina }\end{array}$ & +542965 496-269 & www.efpu.com.ar \\
\hline IAA & $\begin{array}{l}\text { Instituto Antártico } \\
\text { Argentino }\end{array}$ & $\begin{array}{l}\text { Cerrito } 1248 \text { (1010) } \\
\text { Buenos Aires, } \\
\text { Argentina }\end{array}$ & $+54-11-4812-1689$ & www.dna.gov.ar \\
\hline IADO & $\begin{array}{l}\text { Instituto Argentino de } \\
\text { Oceanografía }\end{array}$ & $\begin{array}{l}\text { Casilla de Correos } \\
804 \text { (8000) Bahía } \\
\text { Blanca, Argentina }\end{array}$ & $+54-291-486-1519$ & www.iado.criba.edu.ar \\
\hline INIDEP & $\begin{array}{l}\text { Instituto Nacional de } \\
\text { Investigación y Desarrollo } \\
\text { Pesquero }\end{array}$ & $\begin{array}{l}\text { Paseo Victoria Ocampo } \\
\text { No }^{\circ} 1 \text { (7600) Mar del } \\
\text { Plata, Argentina }\end{array}$ & $+54223486-1830$ & www.inidep.edu.ar \\
\hline MACN & $\begin{array}{l}\text { Museo Argentino de } \\
\text { Ciencias Naturales }\end{array}$ & $\begin{array}{l}\text { Bernardino Rivadavia } \\
\text { Avenida Angel Gallardo } \\
\text { 470, (C1405DJR) } \\
\text { Buenos Aires, Argentina }\end{array}$ & +54-11- 4982-4494 & www.macn.secyt.gov.ar \\
\hline MLP & Museo de La Plata & $\begin{array}{l}\text { Paseo del Bosque s/n } \\
\text { (1900) La Plata, } \\
\text { Argentina }\end{array}$ & $+54-221-425-7527$ & www.fcnym.unlp.edu.ar \\
\hline UBA & Universidad de Buenos Aires & $\begin{array}{l}\text { Ciudad Universitaria } \\
\text { (C1428EHA) Buenos } \\
\text { Aires, Argentina }\end{array}$ & $+54-11-4576-3350$ & www.uba.edu.ar \\
\hline UNMdP & $\begin{array}{l}\text { Universidad Nacional } \\
\text { de Mar del Plata }\end{array}$ & $\begin{array}{l}\text { Funes } 3350(7600) \\
\text { Mar del Plata, } \\
\text { Argentina }\end{array}$ & $+54223475-3150$ & www.mdp.edu.ar \\
\hline UNS & Universidad Nacional del Sur & $\begin{array}{l}\text { Avenida Alem 1253, } \\
\text { (B8000CPB) Bahía } \\
\text { Blanca, Argentina }\end{array}$ & $+54-291-459-5111$ & www.uns.edu.ar \\
\hline UNPSJB & $\begin{array}{l}\text { Universidad Nacional de } \\
\text { la Patagonia San Juan } \\
\text { Bosco (Sede Comodoro } \\
\text { Rivadavia) }\end{array}$ & $\begin{array}{l}\text { Km } 4 \text { (9000) Comodoro } \\
\text { Rivadavia, Argentina }\end{array}$ & $+54-867-2-8837$ & www.unp.edu.ar \\
\hline
\end{tabular}

Fecha de recepción: 05/05/03

Fecha de aceptación: 121/09/03 